\title{
Efficiency of threonine utilization in the growing pigs
}

\section{Eficiencia del uso de treonina para cerdos en fase de crecimiento}

\author{
Marcos S Ceron, ${ }^{1}$ M.Sc, Vladimir de Oliveira, ${ }^{2}$ Ph.D, Arlei B de Quadros, ${ }^{2}$ Ph.D, \\ Clóvis E Gewehr, ${ }^{3}$ Ph.D, Leonardo T Rocha, ${ }^{2}$ Zootec, Débora A Alves, ${ }^{2}$ Zootec.
}

\begin{abstract}
${ }^{1}$ Federal University of Santa Maria (UFSM), Zootecny Departament, Roraima Avenue $\mathrm{n}^{\circ} 1000$,

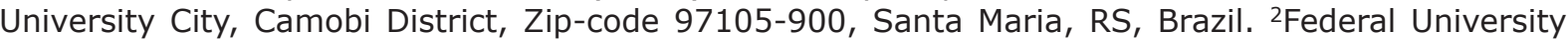
of Santa Maria, Zootecny Departament. 3University of the State of Santa Catarina (UDESC), Animal production departament, Luiz de Camões Avenue, n² 2090, Conta Dinheiro District, Zip-code 88520000, Lages, SC, Brazil.*Correspondence: vladimir.oliveira@ufsm.br
\end{abstract}

Received: November 2014; Accepted: August 2015.

\begin{abstract}
Objective. This study aimed to determine the marginal efficiency of threonine utilization in growing pigs by using the nitrogen balance technique. Materials and methods. Twelve castrated pigs with an average live weight of $72 \pm 2 \mathrm{~kg}$ were housed in metabolic cages maintained in a temperature controlled room of $22 \pm 3^{\circ} \mathrm{C}$. The treatments consisted of four diets calculated to meet $30,45,60$ and $70 \%$ of the nutritional requirements of standardized ileal digestible threonine. The amino acids others than threonine were maintained at least $15 \%$ above threonine requirements, expressed in terms of ideal levels. The amount of feed supplied was calculate to provide 2.6 times the metabolizable energy requirements for maintenance and adjusted daily according to an expected daily gain rate of $0.8 \mathrm{~kg}$. Results. Pigs consumed $1.65 \mathrm{~g} \mathrm{~kg}^{-1} \mathrm{BW}^{0.75}$ nitrogen daily, on average and $61 \%$ was retained and, as a result, $39 \%$ was excreted, being $31 \%$ through the feces and the remainder (69\%) in the urine. The pigs showed a linear retention of threonine in response to the increase of standardized threonine intake. For each gram of standardized threonine intake $0.37 \mathrm{~g}$ were lost during the metabolism. Conclusions. It is concluded that for calculating nutritional requirements of standardized threonine of pigs by the factorial method, it is possible to use the utilization marginal efficiency of 0.63 .
\end{abstract}

Key words: Diet, essential amino acids, nitrogen, pig production, protein, requirements. (Source: Agrovoc).

\section{RESUMEN}

Objetivo. El objetivo de este estudio fue determinar la eficiencia marginal del uso de treonina para cerdos en fase de crecimiento, por medio de la técnica de balance de nitrógeno. Material y métodos. Fueron utilizados doce cerdos machos castrados con peso promedio de $72 \pm 2 \mathrm{~kg}$ alojados en jaulas metabólicas climatizadas a una temperatura ambiente de $22 \pm 3^{\circ} \mathrm{C}$. Los tratamientos consistieron en cuatro dietas calculadas para 30,45, 60 y $70 \%$ de las necesidades nutricionales de treonina digestible estandarizada. Los demás aminoácidos se añadieron a las dietas para lograr una proporción de al menos $15 \%$ de sus necesidades expresadas con relación a la treonina. La cantidad de alimento proporcionado se calculó para suministrar 2.6 veces la energía metabolizable y ajustada todos los dias, según una tasa de ganancia media diaria de $0.8 \mathrm{~kg}$. Resultados. Los cerdos consumieron $1.65 \mathrm{~g} \mathrm{~kg}^{-1} \mathrm{PV} 0.75 \mathrm{de}$ nitrógeno por dia. En promedio $61 \%$ de nitrógeno ingerido se conservó y $39 \%$ fue excretado por el 
animal. El 31\% se excretó en las heces y el resto (69\%) en la orina. Los cerdos mostraron una retención lineal de treonina, con relación al aumento en la ingesta de treonina digestible estandarizada. Por cada gramo de treonina digestible estandarizada ingerido $0.37 \mathrm{~g}$ se perdieron durante el metabolismo. Conclusiones. Se concluye que, para el cálculo de las necesidades nutricionales de treonina digestible estandarizada para cerdos por método factorial, es posible utilizar la eficiencia marginal del uso de treonina a 0.63 .

Palabras clave: Dieta, aminoácidos esenciales, nitrógeno, proteínas, producción de cerdos, requerimientos. (Fuente: Agrovoc).

\section{INTRODUCTION}

Threonine is an indispensable amino acid for pigs and is required for both maintenance and growth. It is the primary amino acid constituent of immunoglobulins and represents a significant portion of the proteins secreted by the small intestine (1). Threonine does not undergo transamination and there is no synthesis of threonine by the pigs. Consequently, all the threonine required by pig must be provide in the diet.

Many experiments were performed in order to determine the nutritional requirements of threonine, and most of them, through the empirical method. However, another method that might be employed to obtain the nutritional requirements of pigs is the factorial one. In that case, the animal's nutritional requirement is defined according to well laid out physiological factors, such as the maintenance of protein structures and protein deposition (2). The estimated requirements for threonine by the factorial method suppose knowledge about maintenance requirement, rate of protein deposition and the post-absorptive utilization efficiency of threonine. Not all the threonine ingested by pig is recovered in body protein and the inefficiency is linked to the physiological processes, basal losses of amino acids of the integumentary and digestive system, nitrogen catabolism and protein turnover (3).

The knowledge of the amino acid efficiency for protein deposition is crucial to improve protein nutrition, which can result in economic improvements and reducing nitrogen losses in feces and urine. There are relatively few studies conducted to evaluate the marginal efficiency of threonine utilization by pigs. Thus, one study was conducted to determine the marginal efficiency of threonine utilization in pigs.

\section{MATERIAL AND METHODS}

Animals and ambient condition. The experiment was performed with 12 castrated

\section{INTRODUCCIÓN}

La treonina es un aminoácido indispensable para los cerdos y se requiere tanto para su mantenimiento como para su crecimiento. Es el componente fundamental de las inmunoglobulinas y representa una parte significativa de las proteínas secretadas por el intestino delgado (1). No sufre transaminación y no es sintetizada por los cerdos. Por consiguiente, toda la treonina requerida se debe proporcionar en la dieta.

Se llevaron a cabo muchos experimentos con el fin de determinar los requerimientos nutricionales de treonina y la mayoría de ellos, se realizaron a través del método empírico. Sin embargo, otro método que se puede emplear para obtener los requerimientos nutricionales de los cerdos es el factorial. En ese caso, estos requerimientos se definen de acuerdo con factores fisiológicos bien establecidos, tales como el mantenimiento de las estructuras de la proteína y la deposición de esta (2). Las necesidades estimadas de la treonina por el método factorial suponen el conocimiento de los requerimientos de mantenimiento, la tasa de deposición de la proteína y la eficiencia de utilización posterior a la absorción de la treonina. No toda la treonina ingerida por el cerdo se recupera en las proteínas corporales y esta ineficiencia está vinculada con procesos fisiológicos, pérdidas basales de aminoácidos en los sistemas tegumentario y digestivo, catabolismo del nitrógeno y renovación de proteínas (3).

El conocimiento de la eficiencia de los aminoácidos para la deposición de proteína es fundamental para mejorar la nutrición proteica, lo que da lugar a mejoras económicas y a la reducción de pérdidas de nitrógeno en heces y orina. Se han efectuado relativamente pocos estudios para evaluar la eficiencia marginal de la utilización de treonina en cerdos. Es por eso que se llevó a cabo un estudio para determinar dicha eficiencia.

\section{MATERIALES Y MÉTODOS}

Los animales y las condiciones ambientales. El experimento se llevó a cabo con 12 cerdos 
pigs of commercial line, in the finishing phase, and with an average live weight of $72 \pm 2 \mathrm{~kg}$. The animals were housed in metabolic cages, with variable widths and heights in order to adjust the area to the weight of the animal, and kept in a controlled environment in order to achieve the average temperature of $22^{\circ}$ Celsius.

Experimental design. The experiment was divided into two periods of 12 days (seven days of adaptation to the experimental conditions and five days of collection). The animals were distributed through a balanced changeover design (4) in four experimental diets, with a total of six replications per treatment and considering the animal as the experimental unit.

Diet characteristic. The diets were prepared using the concept of ideal protein in order to meet $30 \%, 45 \%, 60 \%$ and $70 \%$ of threonine nutritional conditions suggested by the NRC (3). The other amino acids were calculated to achieve a ratio of, at least, $15 \%$ of their requirements expressed in relation to the threonine (5). The calculated and centesimal composition of the experimental diet is presented in table 1 .

Table 1. Calculated and centesimal composition of pigs diets fed with increasing levels of standardized and digestible threonine.

\begin{tabular}{|c|c|c|c|c|}
\hline \multirow{3}{*}{ Ingredients } & \multicolumn{4}{|c|}{ Level of threonine (\% of requirements) } \\
\hline & 30 & 45 & 60 & 70 \\
\hline & \multicolumn{4}{|c|}{$\%$} \\
\hline Corn & 15.600 & 21.840 & 27.760 & 33.850 \\
\hline Soybean meal & 10.400 & 14.560 & 18.510 & 22.560 \\
\hline Starch & 59.870 & 48.930 & 38.500 & 27.810 \\
\hline Sugar & 10.000 & 10.000 & 10.000 & 10.000 \\
\hline Soybean Oil & 1.000 & 1.500 & 2.000 & 2.500 \\
\hline L_Lysine & 0.060 & 0.080 & 0.100 & 0.120 \\
\hline $\mathrm{DL}$ Methionine & 0.050 & 0.070 & 0.090 & 0.115 \\
\hline L_ Tryptophan & 0.015 & 0.020 & 0.025 & 0.035 \\
\hline $\begin{array}{l}\text { Bicalcium } \\
\text { Phosphate }\end{array}$ & 1.500 & 1.500 & 1.500 & 1.500 \\
\hline Limestone & 0.900 & 0.900 & 0.900 & 0.900 \\
\hline Salt & 0.400 & 0.400 & 0.400 & 0.400 \\
\hline $\begin{array}{l}\text { Vitamin and } \\
\text { mineral premix }\end{array}$ & 0.200 & 0.200 & 0.200 & 0.200 \\
\hline \multirow[t]{2}{*}{ Total } & 100.000 & 100.000 & 100.000 & 100.000 \\
\hline & \multicolumn{4}{|c|}{ Nutritional values calculated } \\
\hline ME $($ Kcal kg-1) & 3430 & 3421 & 3414 & 3407 \\
\hline $\mathrm{CP}(\%)$ & 6.35 & 8.60 & 10.74 & 12.95 \\
\hline Threonine (\%) ${ }^{\mathrm{a}}$ & $0.18^{\mathrm{b}}(100)^{\mathrm{c}}$ & $0.25(100)$ & $0.31(100)$ & $0.38(100)$ \\
\hline Lysine (\%) & $0.32(178)$ & $0.44(176)$ & $0.56(181)$ & $0.68(179)$ \\
\hline Methionine (\%) & $0.12(67)$ & $0.16(64)$ & $0.21(68)$ & $0.26(68)$ \\
\hline MET + Cystine (\%) & $0.19(106)$ & $0.26(104)$ & $0.33(106)$ & $0.41(108)$ \\
\hline Tryptophan (\%) & $0.06(33)$ & $0.09(36)$ & $0.11(35)$ & $0.14(37)$ \\
\hline Isoleucine (\%) & $0.20(111)$ & $0.28(112)$ & $0.36(116)$ & $0.44(116)$ \\
\hline Valine (\%) & $0.23(128)$ & $0.32(128)$ & $0.41(132)$ & $0.50(132)$ \\
\hline Leucine (\%) & $0.41(228)$ & $0.57(228)$ & $0.72(232)$ & $0.88(232)$ \\
\hline Phenylalanine (\%) & $0.28(156)$ & $0.39(156)$ & $0.50(161)$ & $0.60(158)$ \\
\hline PHENYL + TYR (\%) & $0.41(228)$ & $0.57(228)$ & $0.73(235)$ & $0.89(234)$ \\
\hline Histidine (\%) & $0.12(67)$ & $0.16(64)$ & $0.21(68)$ & $0.25(66)$ \\
\hline Arginine (\%) & $0.25(139)$ & $0.35(140)$ & $0.44(142)$ & $0.54(142)$ \\
\hline \multicolumn{5}{|c|}{$\begin{array}{l}\mathrm{CP}=\text { crude protein; } \mathrm{ME}=\text { metabolizable energy; MET = methionine; } \\
\mathrm{PHENYL}=\text { phenylalanine; TYR = tyrosine. aValues expressed as } \\
\text { standardized digestible amino acid. bValues obtained by multiplying } \\
\text { the coefficient of standardized digestibility by the values of amino acids } \\
\text { analyzed in corn and soybean bran. cValues in parentheses represent } \\
\text { the relation between lysine and other amino acids in this experiment. }\end{array}$} \\
\hline
\end{tabular}

castrados, de línea comercial, en la etapa de finalización, con un peso vivo promedio de $72 \pm 2$ $\mathrm{kg}$. Los animales se alojaron en jaulas metabólicas, con medidas de ancho y altura variables con el fin de ajustar el área de acuerdo al peso del animal, y se mantuvieron en un ambiente controlado para lograr una temperatura promedio de $22^{\circ}$ Celsius.

Diseño experimental. El experimento se dividió en dos periodos de 12 días (siete días de adaptación a las condiciones experimentales y cinco días de recolección). Los animales se distribuyeron en cuatro dietas experimentales, a través de un diseño de transición balanceado (4), con un total de seis repeticiones por tratamiento y considerando el animal como la unidad experimental.

Características de la dieta. Las dietas se prepararon empleando el concepto de proteína ideal con el fin de proveer el 30\%, 45\%, 60\% y $70 \%$ de las condiciones nutricionales requeridas (CNR) de treonina (3). La cantidad de los demás aminoácidos se calculó para lograr una relación de al menos el $15 \%$ de sus requerimientos expresados en relación con la treonina (5). En la Tabla 1 se presenta la composición centesimal calculada de la dieta experimental.

Procedimiento experimental. La cantidad de alimento se calculó para satisfacer el consumo de 2,6 veces la energía metabolizable de mantenimiento (250 kcal/kg PV ${ }^{0,60}$ ), considerando un ajuste en el consumo diario de alimento de acuerdo con el aumento de peso estimado de $0,8 \mathrm{~kg}$ por día. El alimento se distribuyó en cuatro comidas diarias: a las 8:00 h, 11:00 h. 13:00 h, 18:00 h y se proporcionó agua a voluntad.

Las heces se recolectaron durante cinco días de acuerdo con el método del indicador, utilizando óxido férrico como un marcador indigestible. Las muestras se empacaron en bolsas plásticas y se mantuvieron en un congelador $\mathrm{a}-10^{\circ} \mathrm{C}$. Al final del período experimental, las heces se homogenizaron y se obtuvieron muestras de $0,5 \mathrm{~kg}$, parcialmente secas y molidas para su análisis posterior.

Se drenó la orina en contenedores plásticos que contenían $30 \mathrm{ml}$ de ácido sulfúrico $\left(\mathrm{H}_{2} \mathrm{SO}_{4} 3,5\right.$ $\mathrm{M})$ para impedir la contaminación bacterial y la volatilización del nitrógeno. Se midió el volumen y el $\mathrm{pH}$ de la orina cada 12 horas, se recolectó un $5 \%$ de la muestra y se almacenó a $4^{\circ}$ Celsius. Para cada animal se determinaron los residuos del forraje y los sobrantes, se pesaron y el valor se descontó del consumo de alimento del animal.

Se determinó el contenido de aminoácidos del maíz y la soya empleados en las dietas 
Experimental procedure. The amount of feed was calculated to meet the consumption of 2.6 times the metabolizable energy for maintenance ( $250 \mathrm{kcal} \mathrm{kg}^{-1} \mathrm{BW}^{0.60}$ ), considering an adjustment on daily feed intake according to the estimated weight gain of $0.8 \mathrm{~kg}$ per day. The food was distributed into four meals a day: at 08h:00, $11 \mathrm{~h}: 00,13 \mathrm{~h}: 00,18 \mathrm{~h}: 00$ and water was provided ad libitum.

The feces were collected for five days according to the marker-to-marker approach using ferric oxide as an indigestible marker. The samples were packed into plastic bags and maintained in a freezer at $-10^{\circ} \mathrm{C}$. At the end of the experimental period, the feces were homogenized and samples of $0.5 \mathrm{~kg}$ were obtained, partially dried and grounded for further analysis.

The urine was drained into plastic containers containing $30 \mathrm{ml}$ of sulfuric acid $\left(\mathrm{H}_{2} \mathrm{SO}_{4} 3.5 \mathrm{M}\right)$ to prevent bacterial contamination and nitrogen volatilization. The volume and urinary $\mathrm{pH}$ were measured every 12 hours, and a sample of $5 \%$ was collected and stored at $4^{\circ}$ Celsius. The waste of feed and leftovers was determined to each animal. Subsequently, the feed leftovers were weighed, and the value was discounted from the animal's feed intake.

The content of corn and soybeans amino acids used in the experimental diets were determined by liquid chromatography after acid hydrolysis. The dry matter of the ingredients, feces, feed and leftovers along with the nitrogen ingredients, feed, feces and urine, were determined by the AOAC methodology (6).

The retained nitrogen was obtained by the difference between the nitrogen intake and nitrogen eliminated in feces and urine (nitrogen balance). The protein deposition was calculated by multiplying the retained nitrogen by 0.0625 assuming that nitrogen constitutes $6.25 \%$ of the retained proteins (3).

The amount of threonine retained was calculated through the difference between the ingested standardized threonine and deposited threonine, assuming that it constitutes $3.79 \%$ of the body protein (7). The marginal efficiency of utilization of threonine was obtained by the angular coefficient of the line originated through the regression between the threonine retained and standardized digestible threonine intake (8).

Statistical analysis. The obtained data were submit to variance analysis by using a linear model containing animal, time and treatment as main effects. Subsequently, it was performed a experimentales mediante cromatografía líquida, después de hidrólisis ácida. La materia seca de los ingredientes, heces, forraje y sobrantes junto con los componentes nitrogenados, forraje, heces y orina, fueron determinados según los métodos descritos por la AOAC (6).

El nitrógeno retenido se obtuvo a partir de la diferencia entre la ingesta de nitrógeno y el nitrógeno eliminado en las heces y en la orina (balance de nitrógeno). La deposición de proteína se calculó multiplicando el nitrógeno retenido por 0.0625 , asumiendo que el nitrógeno constituye el $6.25 \%$ del total de proteínas retenidas (3).

La cantidad de treonina retenida se calculó como la diferencia entre la treonina ingerida estandarizada y la treonina retenida, asumiendo que esta constituye el 3,79\% de la proteína corporal (7). La eficiencia marginal de utilización de treonina se obtuvo mediante el coeficiente angular de la línea originada por la regresión entre la treonina retenida y el consumo de treonina digestible estandarizada (8).

Análisis estadístico. Los datos obtenidos se sometieron a análisis de varianza utilizando el modelo lineal que contiene como efectos principales el animal, el tiempo y el tratamiento. Posteriormente, se llevó a cabo un procedimiento de regresión lineal con las medias ajustadas, utilizando el programa Minitab (9).

Aspectos éticos. El protocolo experimental fue aprobado y revisado por el Comité Ético de Experimentación Animal de la Universidad Federal de Santa María (Dictamen 005/2012).

\section{RESULTADOS}

Los animales se mantuvieron saludables durante el período experimental. Las muestras de heces y orina fueron obtenidas sin ningún problema.

En nuestro experimento la dieta con la relación más alta entre treonina digestible estandarizada y energía metabolizable (TDE:EM) presentó un valor de $1.4 \mathrm{~g} /$ Mcal. El consumo de materia seca (CMS) fue diferente entre los tratamientos $(p \leq 0.001)$.

Se presentaron diferencias $(p \leq 0.001)$ en el nitrógeno fecal entre tratamientos (Tabla 2) y se observó un incremento lineal $(p \leq 0.001)$ del nitrógeno fecal en función del consumo de nitrógeno de acuerdo con la pendiente de la relación, que es de 0.165 ( $\mathrm{SE}=0.019$ ). El nitrógeno en la orina (NO) se vio afectado por los tratamientos $(p \leq 0.001)$.

El nitrógeno retenido está linealmente relacionado con su consumo $(p<0.001)$. La pendiente de la 
procedure of linear regression with the adjusted means, and the use of the Minitab program (9).

Ethical aspects. The experimental protocol was reviewed and approved by the Ethics Committee on Animal Experimentation of the Federal University of Santa Maria (Opinion 005/2012).

\section{RESULTS}

The animals remained healthy during the experimental period. Feces and urine samples were obtained without any problem.

In our experiment the diet containing the highest ratio between standardized digestible threonine and metabolizable energy (STD: ME) presented a value of $1.4 \mathrm{~g} \mathrm{Mcal}^{-1}$. The dry matter intake (DMI) differed between the treatments $(p \leq 0.001)$.

There were differences $(p \leq 0.001)$ in fecal nitrogen among treatments (Table 2 ) and was observed increased linearly $(p \leq 0.001)$ in fecal nitrogen according to nitrogen intake with the slope of relationship being of $0.165(\mathrm{SE}=0.019)$. The nitrogen in urine (NU) was influenced by treatments $(p \leq 0.001)$.

Table 2. Dry matter intake, metabolizable energy intake and nitrogen balance of pigs consuming diets with increasing levels of standardized and digestible threonine (values expressed per day).

\begin{tabular}{|c|c|c|c|c|c|c|}
\hline \multicolumn{7}{|c|}{$\begin{array}{l}\text { Levels of threonine } \\
\text { in the diet } \\
\text { (\% of requirements) }\end{array}$} \\
\hline & 30 & 45 & 60 & 70 & EPM & Prob.* \\
\hline Observations & 6 & 6 & 6 & 6 & - & - \\
\hline MBW (BW 0.75 ) & 24.28 & 24.47 & 24.63 & 25.06 & 0.13 & 0.019 \\
\hline DMI $\left(\mathrm{g} \mathrm{kg}^{-1} \mathrm{BW}^{0.75}\right)$ & 92.31 & 91.06 & 91.60 & 91.27 & 0.12 & 0.001 \\
\hline MEI (Kcal kg-1BW ${ }^{0.75}$ ) & 56.9 & 354.8 & 353.4 & 351.4 & 0.48 & 0.001 \\
\hline $\mathrm{NI}\left(\mathrm{g} \mathrm{kg}^{-1} \mathrm{BW}^{0.75}\right)$ & 1.09 & 1.47 & 1.84 & 2.21 & 0.01 & 0.001 \\
\hline $\mathrm{NF}\left(\mathrm{g} \mathrm{kg}^{-1} \mathrm{BW}^{0.75}\right)$ & 0.06 & 0.17 & 0.25 & 0.29 & 0.02 & 0.001 \\
\hline $\mathrm{NU}\left(\mathrm{g} \mathrm{kg}^{-1} \mathrm{BW}^{0.75}\right)$ & 0.31 & 0.34 & 0.50 & 0.57 & 0.03 & 0.001 \\
\hline $\mathrm{NE}\left(\mathrm{g} \mathrm{kg}^{-1} \mathrm{BW}^{0.75}\right)$ & 0.47 & 0.52 & 0.75 & 0.86 & 0.01 & 0.001 \\
\hline NA $\left(\mathrm{g} \mathrm{kg}^{-1} \mathrm{BW}^{0.75}\right)$ & 1.02 & 1.30 & 1.59 & 1.93 & 0.03 & 0.001 \\
\hline $\mathrm{NR}\left(\mathrm{g} \mathrm{kg}^{-1} \mathrm{BW}^{0.75}\right)$ & 0.71 & 0.96 & 1.09 & 1.35 & 0.02 & 0.001 \\
\hline $\mathrm{PD}\left(\mathrm{g} \mathrm{kg}^{-1} \mathrm{BW}^{0.75}\right)$ & 3.81 & 4.93 & 6.08 & 7.46 & 0.11 & 0.001 \\
\hline \multicolumn{7}{|c|}{$\begin{array}{l}\text { MBW = metabolic body weight; } \mathrm{DMI}=\text { dry matter intake; MEI = } \\
\text { metabolizable energy intake; NI = nitrogen intake; NF = nitrogen in } \\
\text { feces; NU = nitrogen in urine; NE = nitrogen excreted; } \mathrm{NA}=\text { nitrogen } \\
\text { absorbed; NR = nitrogen retained; PD = protein deposition; } \mathrm{EPM}=\text { mean } \\
\text { standard error; BW = body weight; Prob. = Probability. }{ }^{*} \text { means adjusted } \\
\text { to the treatment effects. }\end{array}$} \\
\hline
\end{tabular}

The $N$ retention was linearly $(p<0.001)$ associated with $\mathrm{N}$ intake. The slope of regression line relating $\mathrm{NU}$ and NI $0.254(\mathrm{SE}=0.026)$. The slope of relation between retained threonine (RT) and standardized digestible threonine (SDT) intake was $0.63(\mathrm{SE}=0.033)$. línea de regresión relaciona el nitrógeno en la orina (NO) con el consumo de nitrógeno (NC) $0.254(\mathrm{SE}=0.026)$. La pendiente de relación entre la treonina retenida (TR) y el consumo de treonina digestible estandarizada (TDE) es de 0,63 $(\mathrm{SE}=0.033)$.

\section{DISCUSIÓN}

Una importante suposición en la estimación empírica de la eficiencia de los aminoácidos es que la prueba de estos debe constituir la primera restricción nutricional en las dietas experimentales.

La relación (TDE:EM) es menor que la recomendada para la máxima deposición de proteína $(2.0 \mathrm{~g} / \mathrm{Mcal})$ en cerdos con un peso vivo de $70 \mathrm{~kg}$ (3). Además, se suministraron otros aminoácidos diferentes a la treonina para exceder sus requerimientos. Esto indica que la treonina es el primer factor nutricional limitante para la deposición de proteína.

No se había previsto la diferencia en CMS ya que la cantidad de esta afecta el contenido de pérdidas endógenas de aminoácidos. Sin embargo, puesto que la diferencia entre el consumo más bajo y el más alto es de solamente $1.3 \%$ (Tabla 2 ), es posible que la pérdida de endógenos de treonina y de otros aminoácidos no se vea afectada significativamente.

El nitrógeno encontrado en las heces corresponde a un promedio de digestibilidad aparente en dietas experimentales del $83.5 \%$. El nitrógeno en la orina es consistente con lo esperado ya que esta es la principal vía de excreción de nitrógeno, cuando se encuentra por encima de lo requerido.

Los resultados de la retención de nitrógeno están en línea con aquellos encontrados por Libao-Mercado y colaboradores (8) y muestran que la treonina es el primer limitante de la deposición de proteína en las dietas utilizadas en nuestro experimento.

La pendiente de la línea de regresión que relaciona $\mathrm{NO}$ y NC indica que el $25.4 \%$ del nitrógeno consumido se eliminó a través de la orina. Ese valor fue mayor al $16 \%$ obtenido por Heger y colaboradores (10) y menor que el valor de $33 \%$ mencionado por Libao-Mercado (8). Las diferencias pueden estar relacionadas con la composición de las dietas una vez purificadas con proteína de alto valor biológico como las utilizadas por Heger y colaboradores (10), las cuales tienen la tendencia a producir una menor proporción de pérdidas de consumo de nitrógeno en la orina.

Cuando el NO se relaciona con el consumo de nitrógeno digestible (CND) se observa que el nitrógeno eliminado en la orina debido a la no utilización de la deposición de proteínas es de 0.309 


\section{DISCUSSION}

One important assumption in empirical estimate of amino acids efficiency is that the amino acid test must be the first nutritional constraint in the experimental diets.

The ratio STD:ME is lower than the recommended for maximum protein deposition $\left(2.0 \mathrm{~g} \mathrm{Mcal}^{-1}\right)$ of pigs with a live weight of $70 \mathrm{~kg}$ (3). In addition the amino acids others than threonine were supplies to exceed their requirements. This indicates that threonine was the first limiting nutritional factor for protein deposition.

The difference in DMI was not planned because the amount of DMI influences the content of endogenous losses of amino acids. However, since the difference between the lowest and highest consumption was only $1.3 \%$ (Table 2 ), it is possible that the endogenous loss of threonine and other amino acids were barely affected.

The $\mathrm{N}$ found in feces indicating mean apparent $\mathrm{N}$ digestibility of experimental diets was $83.5 \%$. The $\mathrm{N}$ in urine was according to the expectations since the urine is the main route of nitrogen excretion ingested in excess of requirements.

The results of $\mathrm{N}$ retention are in agreement with Libao-Mercado et al (8) and show that the threonine was first limiting to protein deposition in diets used in our experiment.

The slope of regression line relating NU and NI indicated that $25.4 \%$ of nitrogen consumed were eliminated through the urine. That value was bigger than $16 \%$ obtained by Heger et al (10) and smaller than value of 33\% mentioned by LibaoMercado (8). The differences may be associated with the diet composition once purified diets with protein of high biology value as used by Heger et al (10) has a trend to result a lesser proportion of nitrogen intake losses in urine.

When NU was associated with digestible nitrogen intake (DNI) we observed that the $\mathrm{N}$ eliminated in the urine due to non-use for protein deposition was $0.309 \mathrm{~g} \mathrm{~kg}^{-1}$ BW 0.75 for each gram of DNI above of maintenance needs (Figure 1 ). The value was bigger than $16 \%$ obtained by Heger et al (11) who used purified diet containing a protein source of high biological value. The NU has origin from diet $\mathrm{N}$ that's not used to protein synthesis, intestinal endogenous $\mathrm{N}$ secreted and no reabsorbed until the end of small intestine and $\mathrm{N}$ absorbed in large intestine. Therefore, these results emphasize again the importance of protein quality on improve $\mathrm{N}$ utilization in pig production (12). g/kg PV0,75 por cada gramo de CND por encima de las necesidades de mantenimiento (Figura 1). El valor es mayor que el $16 \%$ obtenido por Heger y colaboradores, quienes utilizaron una dieta purificada que contiene una fuente de proteínas de alto valor biológico. El NO se origina a partir de dietas con nitrógeno que no es empleado para la síntesis de proteína, por el nitrógeno endógeno intestinal secretado y no es reabsorbido hasta el final del intestino delgado y por el nitrógeno absorbido en el intestino grueso. Por lo tanto, estos resultados ponen de manifiesto una vez más la importancia de la calidad de la proteína para mejorar la utilización del nitrógeno en la producción porcina (12).

El valor de la relación entre la treonina retenida TR y el consumo de TDE indica que la eficiencia marginal de TDE para la deposición de proteína es del 63\% (Figura 2), la cual es menor al 73.83 y $67 \%$ encontrada por de Lange y colaboradores (7), Heger y colaboradores (10) y Heger y colaboradores (13), respectivamente. Estas discrepancias pueden estar explicadas, al menos parcialmente, por las diferencias entre los aspectos metodológicos encontrados en los estudios interrelacionados.

Suponiendo que la eficiencia del consumo de treonina digestible estandarizada para la retención de proteína en la proteína corporal es el $63 \%$, esto implica que el $37 \%$ de la TDE se pierde debido al inevitable catabolismo mínimo que ocurre incluso cuando el consumo de treonina limita la deposición de proteína. Los principales determinantes fisiológicos de este catabolismo de aminoácidos en cerdos en crecimiento son las pérdidas de aminoácidos endógenos, pérdidas de aminoácidos físicas con la piel y el pelo y pérdidas debido al intercambio proteínico (1). Se considera que la treonina se utiliza con menor eficiencia en la deposición proteica en comparación con otros

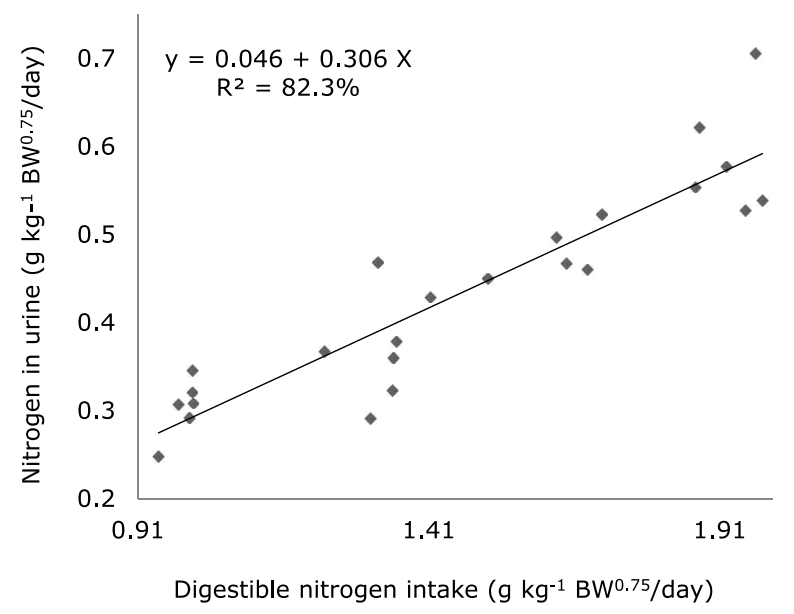

Figure 1. Relationship between digestible nitrogen intake and nitrogen in urine. 
The value of the relation between RT and STD intake indicates that marginal efficiency of SDT for protein deposition is $63 \%$ (Figure 2) which is lower than 73,83 and $67 \%$ found by de Lange et al (7), Heger et al (10) and Heger et al (13), respectively. These discrepancies can be explained at least partially because the differences in the methodological aspects found inter studies.

Assuming that $63 \%$ is the efficiency of standardized digestible threonine intake to protein retention in body protein implies that $37 \%$ of standardized digestible threonine is lost due to inevitable minimum catabolism that occurs even when the threonine intake limits protein deposition. The main physiologic determinants of inevitable minimum catabolism of amino acids in growing pigs are amino acid endogenous losses, physical amino acids losses with skin and hair and losses due to protein turnover (1). It is assumed that threonine is used with lower efficiency to protein deposition compared with other amino acids like lysine and valine, for example (5). Normally it is justified because the intestinal endogenous losses is the major contributing to inevitable catabolism and threonine is particularly important since its participation in intestinal protein mucin is high $(14,15)$.

The information about threonine deposition efficiency is essential to the development of requirement estimates by the factorial method, which in turn is the preferred method for estimating the nutritional requirements of pigs (16) and used in most of the simulation models of growth pigs (17).

In conclusion the marginal efficiency of utilization of 0.63 can be used to calculate the nutritional requirements of threonine by the factorial method.

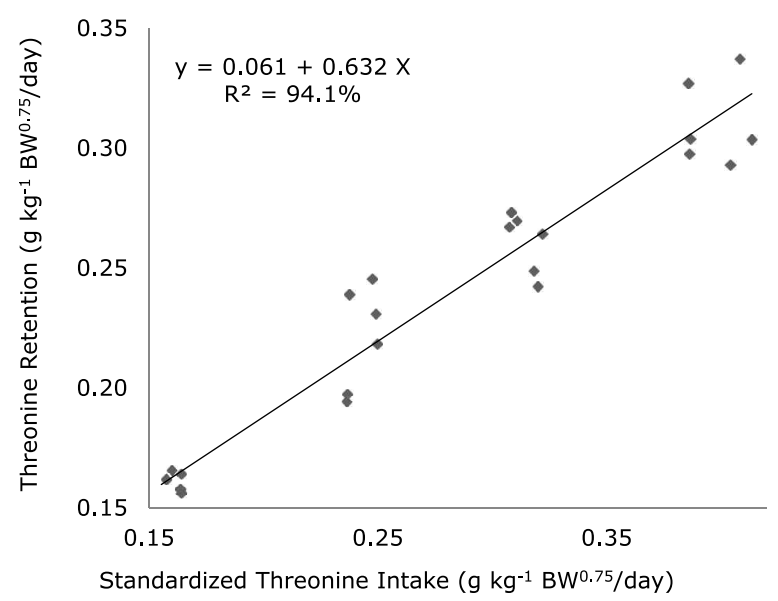

Figure 2. Relationship between standardized digestible threonine intake and threonine retention in pigs fed with increasing levels of threonine.

aminoácidos como la lisina y la valina, a modo de ejemplo (5). Normalmente se justifica porque las pérdidas endógenas intestinales son las principales contribuyentes del catabolismo inevitable y la treonina es particularmente importante ya que su participación en la proteína de la mucina intestinal es alta $(14,15)$.

La información acerca de la eficiencia de la deposición de treonina es fundamental para el desarrollo de las estimaciones de las necesidades mediante el método factorial, que a su vez es el método preferido para la estimación de los requerimientos nutricionales de cerdos (16) y se utiliza en la mayoría de los modelos de simulación de cerdos en crecimiento (17).

En conclusión, el valor de la eficiencia marginal de utilización de 0,63 se puede utilizar para calcular los requerimientos nutricionales de treonina por el método factorial.

\section{REFERENCES}

1. Zhu CL, Rademacher M, de Lange CFM. Increasing dietary pectin level reduces utilization of digestible threonine intake, but not lysine intake, for body protein deposition in growing pigs. J Anim Sci 2005; 83(5):1044-1055.

2. Hauschild L, Pomar C, Lovatto PA. Systematic comparison of the empirical and factorial methods used to estimate the nutrient requirements of growing pigs. Animal 2010; 4(5):714-723.
3. NRC. National Research Council. Nutrient Requirements of Swine, 11th ed. Washington, D.C.: National Academy Press; 2012.

4. van den Borne JJGC, Schrama JW, Heetkamp MJW, Verstegen MWA, Gerrits WJJ. Synchronising the availability of amino acids and glucose increases protein retention in pigs. Animal 2007; 1(5):666-674. 
5. van Milgen J, Valancogne $A$, Dubois $S$, Dourmad J, Sève B, Noblet J. InraPorc: A model and decision support tool for the nutrition of growing pigs. Anim Feed Sci Tech 2008; 143(1-4):387-405.

6. AOAC. Association of Official Analytical Chemists. Official methods of analyses. Ass Agric Chem 18th ed. Washington: AOAC; 2005.

7. de Lange CFM, Gillis AM, Simpson GJ. Influence of threonine intake on whole-body protein deposition and threonine utilization in growing pigs fed purified diets. J Anim Sci 2001; 79(12):3087-3095.

8. Libao-Mercado AJ, Leeson S, Langer $S$, Marty BJ, de Lange CF. Efficiency of utilizing ileal digestible lysine and threonine for whole body protein deposition in growing pigs is reduced when dietary casein is replaced by wheat shorts. J Anim Sci 2006; 84(6):1362-1374.

9. Minitab Statistical Software. 2013. Release 16.1 for windows. Minitab inc. State College PA: USA.

10. Heger J, Krizova L, Sustala M, Nitrayova S, Patras $P$, Hampel D. Individual response of growing pigs to sulphur amino acid intake. J Anim Physiol Anim Nutr 2007; 92(1):18-28.

11. Heger J, Krizova L, Sustala M, Nitrayova S, Patras $P$, Hampel D. Individual response of growing pigs to lysine intake. J Anim Physiol Anim Nutr 2008; 93(5):538-546.
12. van Milgen J, Dourmad J. Concept and application of ideal protein for pigs. J Anim Sci Biotechnol 2015; 15 (6):1-11.

13. Heger J, van Phung T, Krizova L. Efficiency of amino acid utilization in the growing pig at suboptimal levels of intake: Lysine, sulphur amino acids and tryptophan. J Anim Physiol Anim Nutr 2002; 86(5-6):153-165.

14. Blank B, Schlecht E, Susenbeth A. Effect of dietary fibre on nitrogen retention and fibre associated threonine losses in growing pigs. Arch Anim Nutr 2012; 66(2): 86-101.

15. Morel PCH, Melai J, Eady SL, Coles GD. Effect of non-starch polysaccharides and resistant starch on mucin secretion and endogenous amino acids losses in pigs. Asian Australas J Anim Sci 2005; 18(11):1634-1641.

16. Pomar C, Hauschild L, Zhang G, Pomar J, Lovatto PA. Applying precision feeding techniques in growing-finishing pig operations. R Bras Zootec 2009; 38(spe):226-237.

17. Wecke C, Libert F. Optimal dietary lysine to threonine ratio in pigs ( $30-110 \mathrm{~kg}$ bw) derived from observed dietary amino acid efficiency. J Anim Physiol Anim Nutr 2010; 94(6):1-9. 